\title{
A COBRANÇA DE ICMS PELO REGIME DE SUBSTITUIÇÃO TRIBUTÁRIA PARA O RAMO FARMACÊUTICO DE TANGARÁ DA SERRA - MT
}

\author{
Aylon Miranda Sousa ${ }^{1}$ \\ Flávio Amaral Oliveira²
}

\begin{abstract}
RESUMO
O objetivo do estudo é identificar se há conhecimento e acompanhamento dos pagamentos já efetuados pela substituição tributária e se existe um controle para evitar divergências nos pagamentos cobrados do Imposto sobre a Circulação de Mercadorias e Serviços (ICMS) substituição tributária no ramo farmacêutico de Tangará da Serra - Mato Grosso, e verificar se os contribuintes estão efetuando pagamentos em duplicidade. Através de pesquisas sobre a legislação pertinente ao regulamento do ICMS em Mato Grosso foi possível apresentar o material com informações que permitem melhor compreensão sobre a operação de substituição tributária do ICMS no Estado de Mato Grosso para o setor farmacêutico. Para verificação do nível de conhecimento dos empresários e do pagamento em duplicidade foi necessário aplicar questionários que proporcionaram obter resultados para tal identificação. Considera-se que o conhecimento dos empresários pode ser dividido em três níveis, sendo eles: os que sabem pouco ou quase nada, os que possuem um conhecimento regular ou bom e os empresários que possuem um conhecimento elevado ou excelente. A comprovação das cobranças indevidas por parte da SEFAZ/MT foi confirmada pelos empresários e por documentos que comprovam sua ocorrência.
\end{abstract}

Palavras-chave: ICMS substituição tributária. Cobrança indevida. RICMS. SEFAZ/MT

\section{INTRODUÇÃO}

O empresário e a sua assessoria fiscal, na maioria das vezes, o contador, precisa estar atento aos procedimentos de arrecadação do ICMS via Substituição Tributária para que não sejam vítimas do pagamento em duplicidade. Essa observação é importante, pois o pagamento do ICMS Substituição Tributária é efetuado de forma antecipada com retenção do imposto pelo fornecedor, assim, com o poder de tributar a Secretaria de Fazenda do Estado de Mato Grosso poderá gerar débitos que já foram pagos via substituição tributária e que por motivos da não vinculação de tais pagamentos podem ser cobrados novamente, podendo assim prejudicar o contribuinte que sempre honra com suas obrigações tributárias. Por isso, propôsse a pesquisa sobre o tema "A cobrança de ICMS pelo Regime de substituição tributária para o ramo farmacêutico de Tangará da Serra - MT, que busca melhorar o cenário de compreensão do Imposto sobre Circulação de Mercadorias e Serviços (ICMS) ao setor farmacêutico.

\footnotetext{
${ }^{1}$ Acadêmico do curso de Ciências Contábeis da UNEMAT - Campus de Tangará da Serra, aylon_miranda@hotmail.com

${ }^{2}$ Professor do Departamento de Ciências da UNEMAT - Campus de Tangará da Serra, flavioamaral@unemat.br
} 
O problema do setor farmacêutico é se há conhecimento por parte dos empresários em relação ao regime de substituição tributária do ICMS, e se há um acompanhamento dos pagamentos efetuados pelo regime de substituição tributária que previnam contra divergências relacionadas aos valores cobrados pela SEFAZ/MT. Como hipótese menciona-se que os empresários possuem pouco conhecimento ou não são bem assessorados sobre o regime de substituição tributária. Outra hipótese cita-se que pela falta de controle e conferência podem ocorrer duplicidades de pagamento do ICMS decorrente das notas já pagas pelo regime de substituição tributária do ICMS/MT.

O objetivo é identificar se há conhecimento e acompanhamento dos pagamentos já efetuados pela substituição tributária e se existe um controle para evitar divergências nos pagamentos cobrados através do ICMS substituição tributária no setor farmacêutico, pois segundo Oliveira (2007, p. 38) o planejamento tributário é uma forma legal de diminuir a carga tributária através de um grande conhecimento voltado para legislação tributária vigente a fim de pagar o valor exato dos impostos, ou seja, apenas o que é realmente devido. Como objetivos específicos citam-se: pesquisar sobre a legislação do Regulamento do ICMS em Mato Grosso, aplicar questionários que possibilite obter dados suficientes para analisar o nível de conhecimento dos empresários e gestores, verificar se há cobranças indevidas por parte da Secretária de Fazenda do Estado de Mato Grosso aos empresários do ramo farmacêutico e por fim, apresentar um material com informações sobre os procedimentos da substituição tributária.

A justificativa do trabalho se dá pela complexidade da Legislação (RICMS/MT), a ocorrência de cobranças indevidas pela SEFAZ/MT, possibilidade de pagamentos em duplicidade do ICMS, importância do planejamento tributário através do conhecimento e a formação de um material de estudo para o pesquisador, empresários, contabilistas e a sociedade em geral.

\section{REFERENCIAL TEÓRICO}

\subsection{Definições Gerais}

Conceitua Fabretti (2006, p. 29) com a relação à contabilidade tributária como "o ramo da contabilidade que tem por objetivo aplicar na prática conceitos, princípios e normas básicas da contabilidade e da legislação tributária, de forma simultânea e adequada”. 
O estudo da Legislação do ICMS é de fundamental importância para os empresários do ramo farmacêutico que convivem com a compra de produtos decorrentes da substituição tributária, assim, é preciso ter o controle de seus pagamentos e um planejamento tributário que segundo Fabretti (2006, pág. 32) afirma que o planejamento tributário é feito de forma preventiva a fim de procurar "falhas" na legislação tributária e verificar se o custo/benefício é compensador para supri o máximo de ônus tributário.

O ICMS é considerado um tributo, pois segundo o artigo $3^{\circ}$ do Código Tributário Nacional (CTN) da Lei 5.172/66, de 25 de outubro de 1966, é definido como "Tributo é toda prestação pecuniária compulsória, em moeda ou cujo valor nela se possa exprimir, que não constitua sanção de ato ilícito, instituída em lei e cobrada mediante atividade administrativa plenamente vinculada".

Da mesma forma, de acordo com o artigo $5^{\circ}$ do CTN, "Os tributos são impostos, taxas e contribuições de melhoria". Seguindo o mesmo raciocínio, conforme artigo $16^{\circ}$ do CTN, "Imposto é o tributo cuja obrigação tem por fato gerador uma situação independente de qualquer atividade estatal específica, relativa ao contribuinte".

Na hipótese de incidência do imposto é necessário que aconteça determinado fato necessário para caracterizar o surgimento da obrigação tributária, assim, segundo o artigo $114^{\circ}$ do CTN, "Fato gerador da obrigação principal é a situação definida em lei como necessária e suficiente à sua ocorrência”.

Conforme a Receita Federal do Brasil a Nomenclatura Comum do Mercosul (NCM), adotada também por Argentina, Paraguai e Uruguai, são os códigos de classificação fiscal das mercadorias, sendo baseado no Sistema Harmonizado de Designação e de Codificação de Mercadorias, ou simplesmente Sistema harmonizado (SH), tendo como objetivo padronizar e melhorar a organização das mercadorias, afim de satisfazer aos interesses de todos os países membros do Mercosul.

\subsection{ICMS (Imposto sobre a Circulação de Mercadorias e Serviços)}

O ICMS é o imposto sobre operações relativas à circulação de mercadorias e sobre prestações de serviços de transporte interestadual e intermunicipal e de comunicação, e está atribuída aos Governos Estaduais e ao Distrito Federal a competência de instituí-lo de acordo com o artigo 155, inciso II da Constituição federal 1988, "Inciso II - operações relativas à circulação de mercadorias e sobre prestações de serviços de transporte interestadual e 
intermunicipal e de comunicação, ainda que as operações e as prestações se iniciem no exterior".

No Estado de Mato Grosso o ICMS é todo regulamentado pelo Regulamento do ICMS do Estado Mato Grosso (RICMS/MT), atribuído pelo Decreto n. ${ }^{\circ}$ 1.944, de 06 de outubro de 1989, é nele que será direcionado todas as informações relativas às operações estaduais e principalmente em relação ao ICMS.

De acordo com o artigo 2 do RICMS/MT, o fato gerador do ICMS é simplesmente a circulação de mercadorias e serviços, aplicando a alíquota interna de $17 \%$ conforme o artigo 14, da Lei 7.098, de 30 de dezembro de 1998.

\subsection{Substituição Tributária}

A Substituição Tributária pode ser definida como sendo uma forma antecipada de cobrança do imposto, cuja retenção para pagamento é atribuída ao fornecedor vinculado ao fato gerador da obrigação. Está prevista no artigo 150, $\S 7^{\circ}$ da Constituição Federal de 1988, no artigo $6^{\circ}, \S 1^{\circ}$, da Lei Complementar $n^{\circ} 87 / 96$ e pelo Anexo XIV das normas relativas ao regime de substituição tributária, aplicadas a cada segmento econômico, do RICMS/MT, adotado pela SEFAZ/MT para normatizar a cobrança do ICMS via Substituição, a partir de 01/06/2008.

O Contribuinte do ICMS é definido no RICMS/MT pelo artigo 10, do título II, capítulo I, como sendo:

Contribuinte é qualquer pessoa, física ou jurídica, que realize, com habitualidade ou em volume que caracterize intuito comercial, operações de circulação de mercadorias ou prestações de serviços de transporte interestadual e intermunicipal e de comunicação, ainda que as operações e as prestações se iniciem no exterior.

$\mathrm{Na}$ operação da substituição tributária há duas figuras distintas: o Contribuinte Substituto e o Contribuinte Substituído, dessa forma, o Contribuinte Substituto será o responsável pelo recolhimento antecipado do ICMS, se o mesmo estiver situado em outra unidade federada, a escolha do regime de substituição tributária será o da legislação tributária do Estado de destino, ou seja, se as operações promoverem como destino o Mato Grosso será o RICMS/MT.

De outro lado, encontra-se o contribuinte com o intuito de compra para comercialização, o Contribuinte Substituído, assim, a nota fiscal emitida pelo fornecedor indicará o total da nota fiscal que acobertou a operação e no campo "Valor do ICMS 
Substituto" localizado na nota fiscal será descrito o valor que foi retido pelo Contribuinte Substituto, e tal valor será acrescido no total da nota fiscal, pois o Contribuinte Substituído será quem já pagou o imposto e desse modo estará encerrado a cadeia tributária, porém, a responsabilidade de fazer essa cobrança fica atribuída ao Contribuinte Substituto, como previsto no artigo 13-B do RICMS/MT:

Fica atribuída a condição de substituto tributário a:

I - industrial, comerciante ou outra categoria de contribuinte, pelo pagamento do imposto devido na operação ou operações anteriores; II - produtor, extrator, gerador, inclusive de energia, industrial, distribuidor, comerciante ou transportador pelo pagamento do imposto devido nas operações subseqüentes;

III - depositário, a qualquer título, em relação a mercadoria depositada por contribuinte;

IV - contratante de serviço ou terceiro que participe da prestação de serviços de transporte interestadual e intermunicipal e de comunicação"

De acordo com o artigo 291 do RICMS/MT, não se farão a retenção do imposto:

I - nas operações que destinem mercadorias a sujeito passivo por substituição, da mesma mercadoria. (Ex: saída de fabricante de colchão para outra indústria de colchão).

II - nas transferências para outro estabelecimento, exceto varejista, do sujeito passivo por substituição, hipótese em que a responsabilidade pela retenção do recolhimento do imposto recairá sobre o estabelecimento que promover a saída da mercadoria com destino a empresa diversa;

III - nas operações que destinem produtos para integração ou consumo em processo de industrialização;

IV - quando a operação subseqüente a ser realizada pelo estabelecimento destinatário, exceto microempresa, estiver amparada por isenção, não incidência ou diferimento do imposto;

$\mathrm{V}$ - nas operações que destinem mercadorias a consumidor final, ressalvado o diferencial de alíquotas no $\S 3^{\circ}$ do artigo 289 e no inciso I do $\S 1^{\circ}$ do artigo 297.

Em Tangará da Serra - MT segundo setor de Fiscalização e Alvará da Prefeitura Municipal existem 44 (quarenta e quatro) estabelecimentos considerados farmácias e drogarias ativas e devidamente registradas até a data de consulta do dia 08/04/2011. Conforme o Anexo XIV das normas relativas ao regime de substituição tributária, aplicadas a segmentos econômicos, do RICMS/MT, os produtos do ramo farmacêuticos são definidos como substitutos para recolhimento do ICMS conforme Capítulo IV que trata sobre produtos farmacêuticos, soros e vacinas de uso humano e correlatos.

Todavia segue o quadro $n^{\circ} 01$ da relação dos produtos do ramo farmacêutico que são considerados substitutos tributários de acordo com o RICMS/MT, ou seja, o ICMS de todos os produtos a seguir, necessariamente, deve ser recolhido de forma antecipada antes da mercadoria ser objeto de trâmite:

Quadro 01: Produtos substitutos tributários segundo o RICMS/MT. 


\begin{tabular}{|c|c|c|}
\hline ITEM & DESCRIÇÃO & NCM \\
\hline \multicolumn{3}{|c|}{$\begin{array}{l}\text { 4.1. Mercadorias incluídas no regime de substituição tributária conforme Convênio ICMS 76/94 Protocolos } \\
\text { ICMS 24/2005, 7/2008. }\end{array}$} \\
\hline 4.1 .1 & Soros e vacinas, exceto para uso veterinário & 3002 \\
\hline 4.1 .2 & Medicamentos, exceto para uso veterinário & 3003 \\
\hline 4.1 .3 & $\begin{array}{l}\text { Algodão, atadura, esparadrapo, haste flexível ou não, com uma ou } \\
\text { ambas extremidades de algodão, gazes, pensos, sinapismos, e outros, } \\
\text { impregnados ou recobertos de substâncias farmacêuticas ou } \\
\text { acondicionados para venda a retalho para usos medicinais, cirúrgicos } \\
\text { ou dentários, bem como para higiene ou limpeza. "(cf. inciso III do } \\
\text { Anexo Único do Convênio ICMS } 76 / 94 \text {, alterado pelo Convênio } \\
\text { ICMS 88/2009 - efeitos a partir de } 1^{\circ} \text { de novembro de 2009" }\end{array}$ & $\begin{array}{l}3005 \\
5601\end{array}$ \\
\hline 4.1 .4 & Mamadeiras de borracha vulcanizada, vidro e plástico & $\begin{array}{r}4014.90 .90 \\
7013.3 \\
3924.10 .00\end{array}$ \\
\hline 4.1 .5 & Chupetas e bicos para mamadeiras e chupetas & 4014.90 .90 \\
\hline 4.1 .6 & Absorventes higiênicos, de uso interno e externo & $\begin{array}{r}5601.10 .00 \\
4818.40\end{array}$ \\
\hline 4.1 .7 & Preservativos & 4014.10 .00 \\
\hline 4.1 .8 & Seringas & 9018.31 \\
\hline 4.1 .9 & Agulhas para seringas & 9018.32 .1 \\
\hline 4.1 .10 & Pastas e escovas dentifrícias & 3306.10 .00 \\
\hline 4.1 .12 & Provitaminas e vitaminas & 2936 \\
\hline 4.1 .13 & Contraceptivos (dispositivos intra-uterinos - DIU) & 9018.90 .9 \\
\hline 4.1 .14 & Fio dental e fita dental & 3306.20 .00 \\
\hline 4.1 .15 & Preparação para higiene bucal e dentária & 3306.90 .00 \\
\hline 4.1 .16 & Fraldas descartáveis ou não & $\begin{array}{r}4818.40 .10 \\
5601.10 .00 \\
6111 \\
6209\end{array}$ \\
\hline 4.1 .17 & $\begin{array}{l}\text { Preparações químicas contraceptivas à base de hormônios ou } \\
\text { espermicidas }\end{array}$ & 3006.60 \\
\hline 4.1 .18 & $\begin{array}{l}\text { Preparações opacificantes (contrastantes) para exames radiográficos e } \\
\text { reagentes de diagnóstico concebidos para serem administrados ao } \\
\text { paciente (cf. inciso XVIII do Anexo Único do Convênio ICMS } \\
76 / 94 \text {, acrescentado pelo Convênio ICMS } 134 / 2010 \text { - efeitos a partir } \\
\text { de } 1^{\circ} \text { de dezembro de } 2010 \text { ) }\end{array}$ & 3006.30 \\
\hline
\end{tabular}

Fonte: RICMS da SEFAZ/MT

Ainda de acordo com informações da Receita Federal do Brasil, as empresas são classificadas por códigos segundo suas atividades econômicas denominado de CNAE (Código Nacional de Atividades Econômicas), sendo, portanto, uma classificação com o objetivo de padronizar os códigos de identificação de cada ramo produtivo do país nos cadastros dos órgãos públicos. A classificação atual é a versão 2.0 do CNAE, com 1301 subclasses, aprovada e divulgada pela Resolução CONCLA (Comissão Nacional de Classificação) no 01 , de 04/09/2006, que está em vigor desde janeiro de 2007.

Dessa maneira fica uma classificação padrão e de fácil identificação e visualização de determinada ramo econômico, impedindo também certas "confusões" com benefícios 
tributários, já que os mesmos são definidos por atividades econômicos com apresentação dos CNAE's que se enquadram.

\subsubsection{Do Cálculo pela Substituição Tributária}

De acordo com a nova regra de cálculo do ICMS por Substituição Tributária de produtos do ramo farmacêutico e medicamentos, fica alterado o artigo 37 do Anexo VIII do RICMS/MT, e passa a vigorar com as alterações previstas no Decreto $\mathrm{n}^{\mathrm{o}} 1845$ de 11 de março de 2009, que de acordo com a Secretaria de Fazenda do Estado de Mato Grosso (SEFAZ/MT) foi reduzido à carga tributária final relativa ao Imposto sobre a Circulação de Mercadorias e Prestação de Serviços (ICMS) e as medidas beneficiam tanto a indústria como o comércio varejista e atacadista de produtos farmacêuticos e hospitalares de Mato Groso, que recolhem o ICMS pelo regime de substituição tributária. No entanto, para usufruir dessas vantagens, as empresas do segmento desse benefício têm que estarem regulares em relação a sua situação fiscal perante a Secretaria de Fazenda do Estado.

De acordo com as alterações decorrentes do Decreto $n^{\circ} 1845$ de 11 de março de 2009, o benefício fiscal concedido aos produtos do ramo farmacêuticos na apuração do cálculo do ICMS via Substituição Tributária deve ser levado em consideração em primeiro lugar o CNAE Fiscal do destinatário (analisando pela visão do Contribuinte Substituto), pois para cada tipo de CNAE será aplicado uma respectiva MVA (Margem de Valor Agregado) definida pela SEFAZ e um coeficiente para apurar a base de Cálculo do ICMS Substituição Tributária, assim no quadro $\mathrm{n}^{\circ} 02$ temos:

Quadro 02: CNAE's mais comuns no ramo farmacêutico.

\begin{tabular}{|l|l|r|r|}
\hline CNAE & Descrição do CNAE & MVA & Coeficiente \\
\hline $4771-7 / 01$ & $\begin{array}{l}\text { Comércio Varejista de Produtos Farmacêuticos, sem Manipulação } \\
\text { de Fórmulas. }\end{array}$ & $33 \%$ & $66,35 \%$ \\
\hline $4771-7 / 02$ & $\begin{array}{l}\text { Comércio Varejista de Produtos Farmacêuticos, com Manipulação } \\
\text { de Fórmulas. }\end{array}$ & $33 \%$ & $66,35 \%$ \\
\hline $4771-7 / 03$ & Comércio Varejista de Produtos Farmacêuticos Homeopáticos. & $33 \%$ & $66,35 \%$ \\
\hline $4644-3 / 01$ & Comércio Atacadista de Medicamentos e Drogas de Uso Humano. & $35 \%$ & $66,36 \%$ \\
\hline $2110-6 / 00$ & Fabricação de Produtos Farmoquímicos. & $55 \%$ & $65,36 \%$ \\
\hline $2121-1 / 01$ & Fabricação de Medicamentos Alopáticos para Uso Humano. & $55 \%$ & $65,36 \%$ \\
\hline $2121-1 / 02$ & Fabricação de Medicamentos Homeopáticos para Uso Humano. & $55 \%$ & $65,36 \%$ \\
\hline $2121-1 / 03$ & Fabricação de Medicamentos Fitoterápicos para Uso Humano. & $55 \%$ & $65,36 \%$ \\
\hline
\end{tabular}


A carga tributária final deverá ser equivalente ao artigo 37, Inciso I do Anexo VII do RICMS/MT:

\begin{abstract}
$11,5 \%$ (onze inteiros e cinco décimos por cento) do valor da operação com mercadorias destinadas a revenda ou a emprego em processo industrial, após o acréscimo ao valor total exarado na Nota Fiscal que acobertou a respectiva aquisição, da margem de lucro de que trata o artigo $1^{\circ}$ do Anexo XI;
\end{abstract}

No entanto, essa carga tributária será limitada em conformidade com o $\S 2^{\circ}$ do artigo 37, Inciso I do Anexo VII do RICMS/MT como: "Na hipótese do inciso I do caput, na operação ou prestação regular e idônea, o ajuste autorizado neste artigo ficará limitado a 15\% (quinze por cento) do valor total da Nota Fiscal que acobertou a respectiva aquisição da mercadoria".

Dessa maneira, segue um demonstrativo como modelo de cálculo do ICMS para um destinatário no Estado de Mato Grosso com CNAE 4771-7/01:

Valor total da nota fiscal. $10.000,00$

Base de cálculo do ICMS origem $10.000,00$

MVA por CNAE fiscal.

Base de cálculo ajustada (somada com o MVA) $13.300,00$

Coeficiente por CNAE fiscal. $66,35 \%$

Base de cálculo reduzida ICMS ST $8.824,55$

Alíquota interna $17 \%$

ICMS substituição tributária. $\mathbf{1 . 5 0 0 , 1 7}$

Ou simplesmente o valor total da nota fiscal de 10.000,00 vezes a MVA de 0,01\%, multiplicada pelo limite de $15 \%$, assim teremos o valor total de $1.500,15$, conforme cobrança e cálculos efetuados pela SEFAZ/MT via Garantido Integral. Dessa maneira, ambos os cálculos estarão corretos, pois estão em conformidade com as alterações previstas no Decreto $\mathrm{n}^{\mathrm{o}} 1.845 / 2009$.

No entanto, em 30 de maio de 2011 foi instituído o Decreto 392 que atualiza as formas de cobrança do ICMS através da implantação do sistema de arrecadação do ICMS por Carga Média, onde para cada atividade econômica representada por um CNAE será aplicada uma porcentagem média, no ramo farmacêutico apesar das atualizações a alíquota final permanece a mesma, ou seja, $15 \%$ (quinze por cento). 


\subsection{Arrecadação do ICMS Via Substituição Tributária}

Para arrecadação do ICMS, o contribuinte substituto precisa ter uma inscrição de substituição tributária cadastrada no estado de origem do destinatário da mercadoria como determina a cláusula sétima do CONFAZ (Conselho Nacional de Política Fazendária) que estabelece que o sujeito passivo por substituição deve se inscrever no cadastro da SEFAZ da unidade federativa do destinatário. Após o cadastro, no Estado de Mato Grosso, o ICMS é recolhido pelo Documento de Arrecadação - Modelo DAR-1/AUT disponível para preenchimento no portal da Secretária de Fazenda do Estado de Mato Grosso.

O ICMS é apresentado como não cumulativo, dessa maneira deve haver uma compensação dos créditos que já foram pagos anteriormente mesmo em outro estado, como trata o artigo $3^{\circ}$ do Decreto-Lei $n^{\circ}$ 406, de 31 de dezembro de 1968: “Art. $3^{\circ}$ : O imposto sobre circulação de mercadorias é não cumulativo, abatendo-se, em cada operação, o montante cobrado nas anteriores, pelo mesmo ou outro Estado."

Com o pagamento pela substituição tributária fica encerrado a cadeia tributária, com isso, não se pode cobrar novamente o ICMS já pago pelo mesmo fato gerador. Como previsto no artigo 292 do RICMS/MT: “A antecipação do imposto pelo regime de substituição tributária encerrará a fase de tributação da mercadoria e não dará ensejo à utilização de crédito fiscal pelo adquirente das mesmas, salvo exceções previstas”.

\section{PROCEDIMENTOS METODOLÓGICOS}

A metodologia utilizada foi à pesquisa bibliográfica e descritiva através da aplicação de questionários com perguntas abertas e fechadas no setor farmacêutico, para assim, obter os dados primários necessários, outro levantamento de dados foi a pesquisa efetuada na Prefeitura Municipal sobre a quantidade e a localização dos estabelecimentos do ramo de drogarias e farmácias de Tangará da Serra - MT.

A definição dos níveis de conhecimentos dos empresários será pelo valor de cada questão respondida, conforme os empresários acertam ou erram, os mesmos são definidos em três níveis de conhecimento: os que sabem pouco ou quase nada, acertaram uma ou nenhuma questão, os que possuem um conhecimento regular ou muito, acertaram duas ou três questões e os que possuem um conhecimento elevado ou excelente, acertaram quatro questões. 
Os dados secundários foram pesquisados com leitura de livros, artigos, legislações de ordem tributárias e outras publicações relacionadas ao tema, assim como o Regulamento do ICMS disponível no site da Secretária de Fazenda do Estado de Mato Grosso (SEFAZ- MT) www.sefaz.mt.gov.br. $\mathrm{O}$ estudo delimitou-se apenas aos empresários, gerentes ou representantes dos estabelecimentos do ramo farmacêutico, tais como farmácias e drogarias localizadas na cidade de Tangará da Serra - Mato Grosso, pesquisados nos meses de junho a setembro de 2011.

Com relação aos entrevistados, apesar de existir 44 estabelecimentos comerciais do setor farmacêutico em Tangará da Serra - MT, o mesmo é composto por 35 representantes e 9 filiais, sendo irrelevante a entrevista novamente, com isso a pesquisa foi realizada com os 35 representantes, sendo eles: empresários, gerentes e outros representantes, tendo 30 questionários respondidos, ou seja, de todo o cenário delimitado $86 \%$ participaram da pesquisa.

\section{ANÁLISE DOS RESULTADOS}

Dos entrevistados $49 \%$ são proprietários, $34 \%$ são gerentes e $3 \%$ estão em outros cargos como, por exemplo, o farmacêutico, dessa forma pode se analisar o gráfico $\mathrm{n}^{\mathrm{o}} 01$ :

Gráfico 01: Cargos dos Entrevistados.

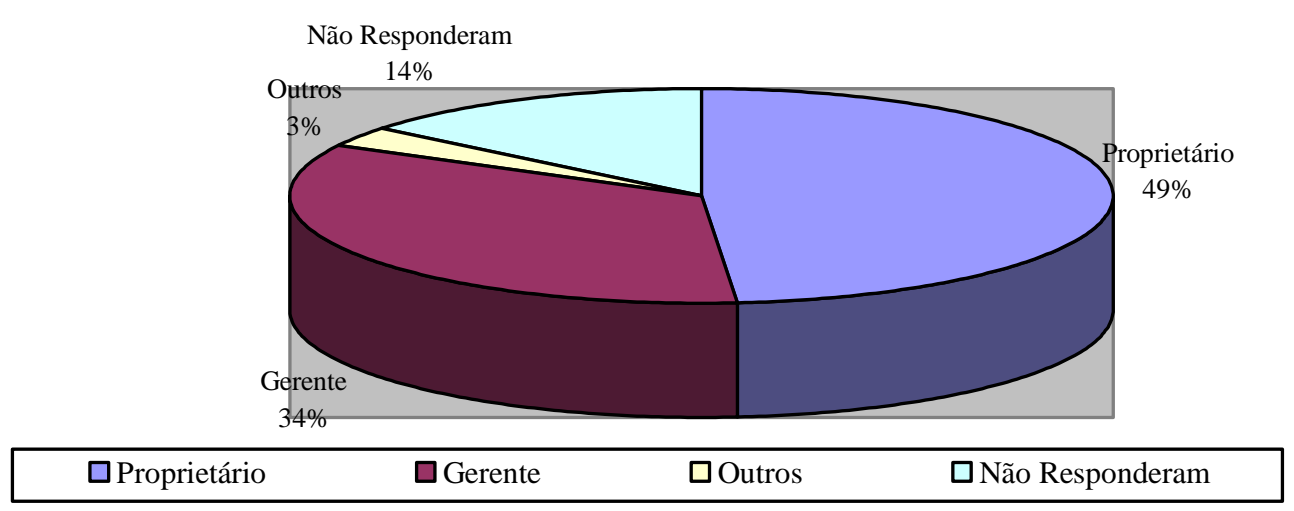

Fonte: dados da pesquisa. 
O resultado demonstra que o número de empresários que estão à frente da empresa ainda é superior aos outros cargos que possuem a função de apenas administrar. Verificando se os empresários sabem definir como é a forma de cobrança do ICMS Substituição Tributária no Estado de Mato Grosso consideramos que de acordo com o gráfico 02 foi elencado várias alternativas para os mesmos responderem, afim de identificar se realmente os empresários conhecem o regime em discussão, dessa forma temos:

Gráfico 02: Definição de Substituição Tributária pelos entrevistados.

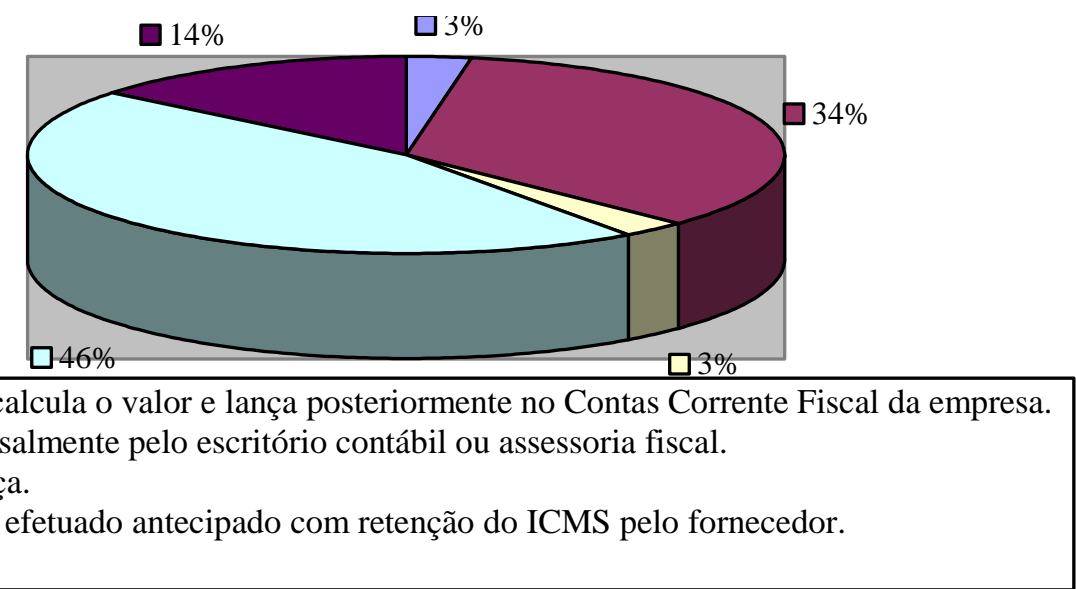

Fonte: dados da pesquisa.

A resposta correta seria a quarta alternativa do gráfico 2 (É o pagamento efetuado antecipado com retenção do ICMS pelo fornecedor), com isso, verificamos que $46 \%$ dos entrevistados responderam corretamente a pergunta, sendo que o restante se equivocaram, percebendo também que a maioria que assinalou erroneamente optaram pela segunda alternativa (É apurado mensalmente pelo escritório contábil ou assessoria fiscal), o que não há nenhuma ligação com o regime por substituição tributária do ICMS no Estado de Mato Grosso.

Como o regime em discussão ocorre com mercadorias vindas de outros Estados, perguntou-se a respeito da porcentagem de compras de mercadorias adquiridas fora do Estado pelos empresários do setor farmacêutico, conforme gráfico 03:

Gráfico 03: Proporção de compras fora do Estado. 


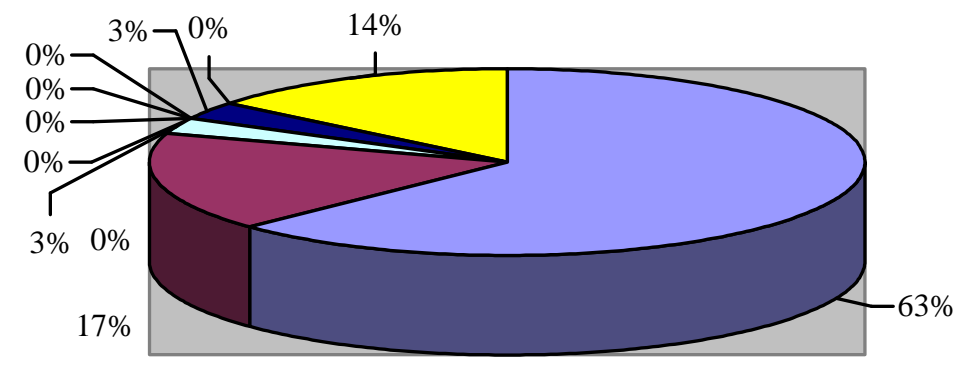

\begin{tabular}{|lll|}
\hline$\square 0 \%$ a $10 \%$ & $\square 11 \%$ a $20 \%$ & $\square 21 \%$ a $30 \%$ \\
$\square 31 \%$ a $40 \%$ & $\square 41 \%$ a $50 \%$ & $\square 51 \%$ a $60 \%$ \\
$\square 61 \%$ a $70 \%$ & $\square 71 \%$ a $80 \%$ & $\square 81 \%$ a $90 \%$ \\
$\square 91 \%$ a $100 \%$ & $\square$ Não Responderam & \\
\hline
\end{tabular}

Fonte: dados da pesquisa.

Assim, evidenciou-se que $63 \%$ dos entrevistados compram o mínimo fora do Estado, cerca de 0 a 10 por cento das compras totais da entidade.

Das compras efetuadas fora do Estado o questionamento procurou abordar se os fornecedores estão fazendo a devida retenção, com isso segue os resultados como apresentado no gráfico 04:

Gráfico 4: Retenção do ICMS por parte dos Fornecedores.

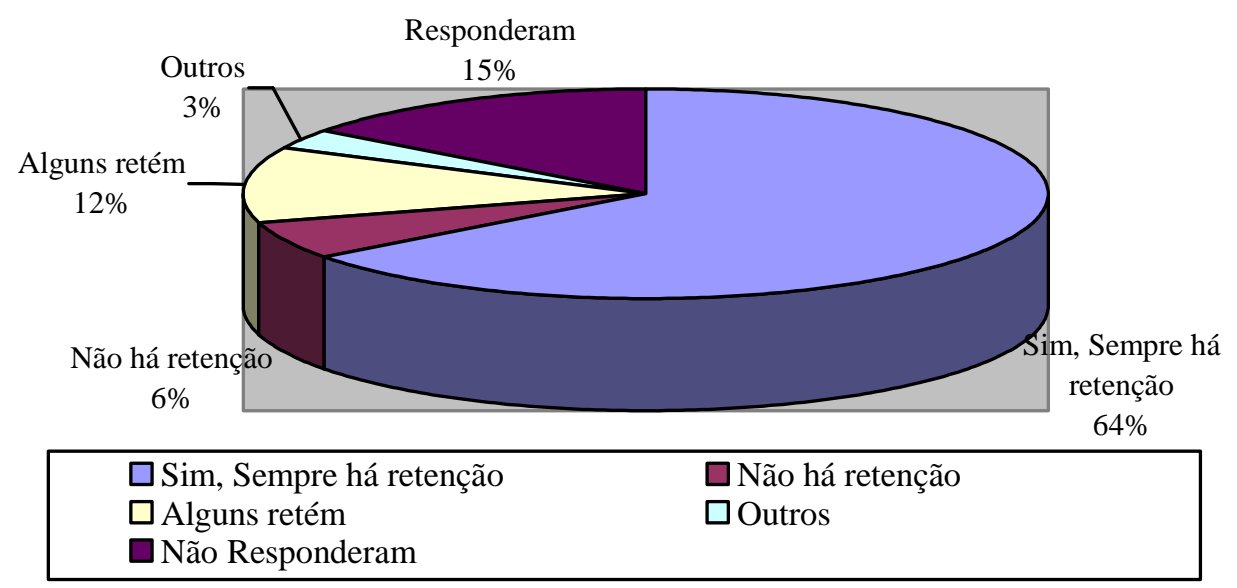

Fonte: dados da pesquisa.

Percebe-se que de acordo com os entrevistados $64 \%$ dos fornecedores sempre fazem a devida retenção do ICMS nas operações de substituição tributária, mostrando que a maioria dos fornecedores estão cumprindo com as suas obrigações na situação de substituto tributário, outros fornecedores nem sempre fazem a retenção, cerca de $12 \%$, e há os que não estão fazendo a retenção, cerca de $6 \%$, evidenciando que segundo os entrevistados há fornecedores que não fazem a devida retenção, podendo a mercadoria ficar apreendida nos postos físcais do Estado de Mato Grosso. 
Em relação à retenção do ICMS pelo fornecedor, o questionário perguntou se antes das compras fora do Estado à empresa é orientada a respeito da observação dos produtos cujo ICMS deve ser pago antecipadamente via substituição tributária, ou seja, há produtos que obrigatoriamente devem ser pagos antecipados, como demonstrado no quadro 1 no ponto 2.3 do referencial teórico, com isso segue os resultados no gráfico 05 :

Gráfico 05: Produtos substitutos tributário do ICMS.

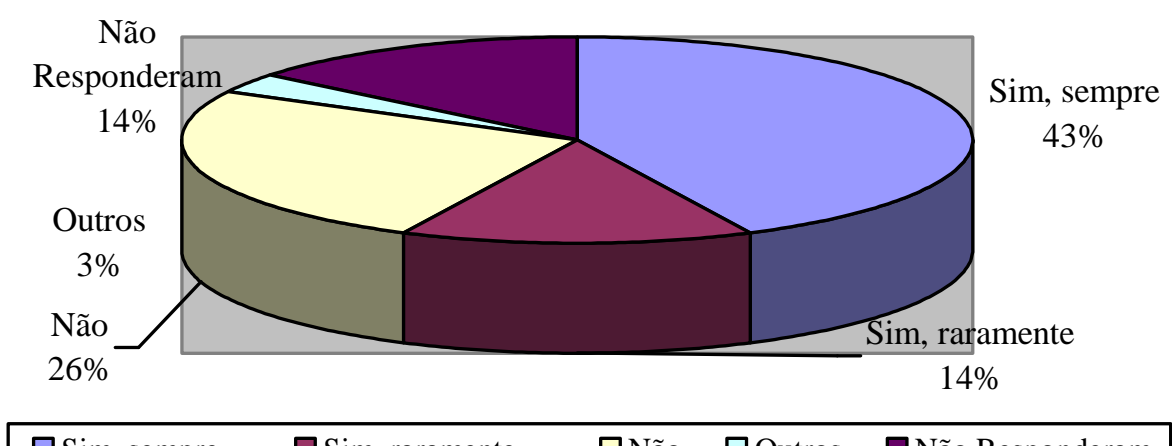

Fonte: dados da pesquisa.

Com isso percebe-se que $43 \%$ dos entrevistados afirmaram que sempre são orientados, $14 \%$ afirmaram que raramente são orientados, e $26 \%$ não são orientados e $3 \%$ optaram por outras opções. Dessa maneira, percebe-se que apesar da grande maioria está sendo orientada, ainda há uma parte significativa que não está sendo.

Dos que responderam que são orientados $5 \%$ afirmaram que essa orientação é feita pela Assessoria Fiscal e 95\% pelo escritório contábil ou Contador, como se pode observar no gráfico 06:

Gráfico 06: Orientação a respeito dos produtos substitutos tributários. 


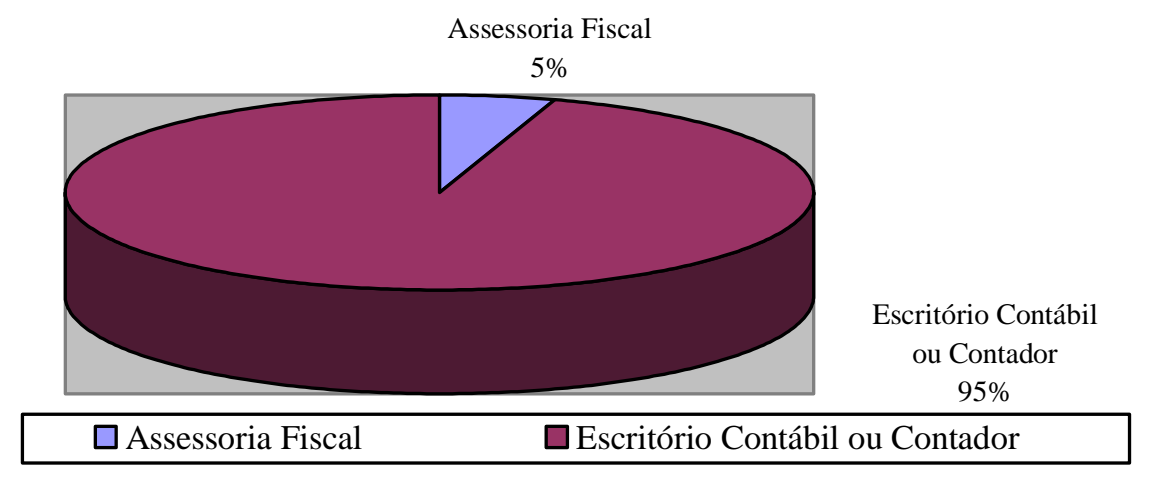

Fonte: dados da pesquisa.

Analisa-se, contudo, que a grande parte das orientações são feitas pelos escritórios de contabilidade ou contador, pois a maioria das empresas em Tangará da Serra - MT possuem esse tipo de assessoria.

Há produtos do ramo farmacêutico que necessariamente o ICMS deve ser pago antecipado, com isso foi perguntado aos entrevistados para que marcassem os produtos que os mesmos julgam serem substitutos tributários do ICMS no Estado de Mato Grosso, com isso no gráfico 07 temos:

Gráfico 07: Porcentagem de acerto de produtos substitutos.

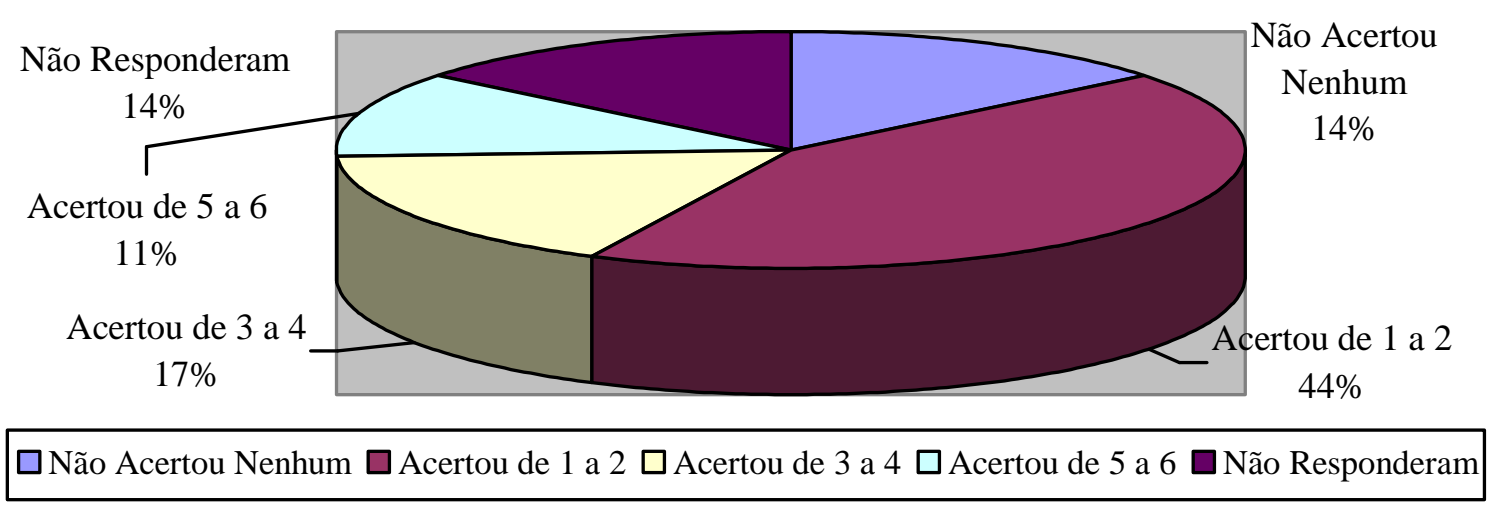

Fonte: dados da pesquisa.

Com relação ao cálculo do ICMS Substituição Tributária, foi proposto aos entrevistados que fizessem o cálculo da compra de um produto do ramo farmacêutico decorrente de substituição tributária, vindo do Estado de São Paulo no valor de 100,00 reais, com isso, a resposta correta seria a alternativa com o resultado de 15,00 reais, pois a alíquota final do ramo farmacêutico é $15 \%$, portanto, 100 vezes $15 \%$ é igual a 15 , dessa maneira segue os resultados da pesquisa no gráfico 08 : 
Gráfico 08: Cálculo do ICMS Substituição Tributária pelos entrevistados.

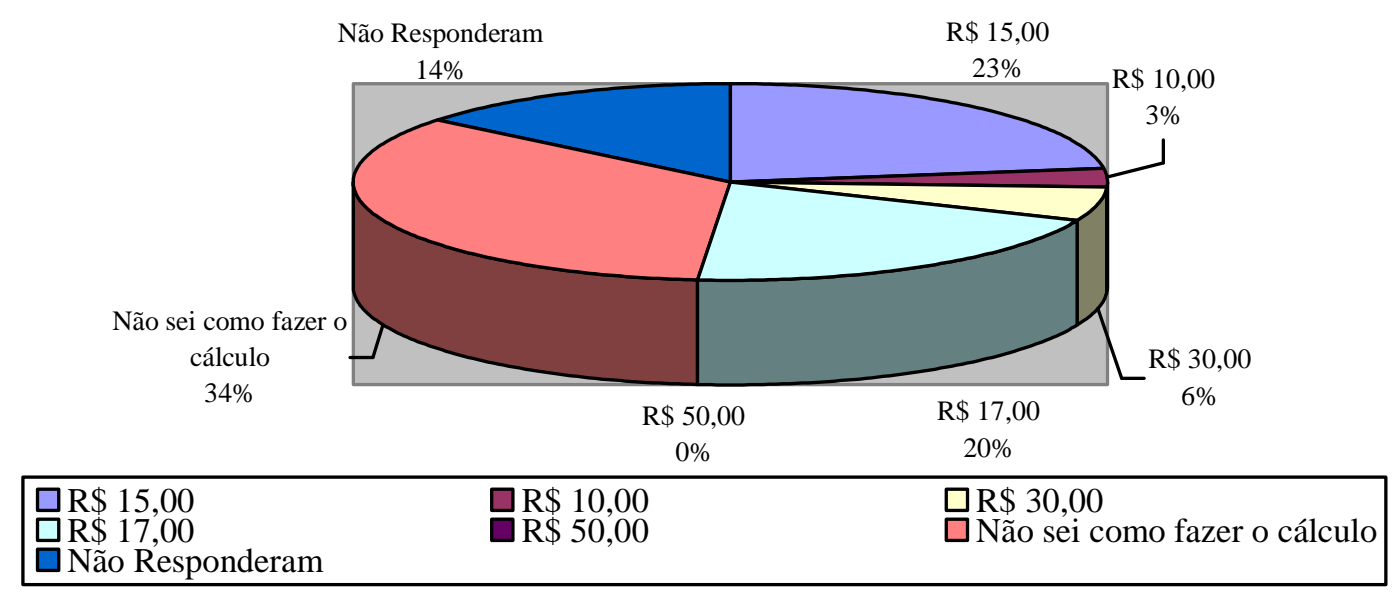

Fonte: dados da pesquisa.

Os resultados mostram que $23 \%$ calcularam o valor correto, ou seja, chegaram aos 15 reais, mostrando que há empresários que sabem fazer o cálculo corretamente, por outro lado há empresários que de imediato afirmaram não saber fazer o cálculo, cerca de 34\% e os outros que tentaram efetuar o cálculo cerca de $29 \%$ não responderam corretamente, percebe-se que há uma grande confusão com relação a alíquota interna de $17 \%$ com a alíquota de $15 \%$ do ramo farmacêutico, pois $20 \%$ dos entrevistados marcaram a opção de 17,00 como a resposta correta.

Verificando se há algum tipo de conferência das notas fiscais que já foram pagas pelo ICMS Substituição Tributária das notas fiscais que não foram pagas, pois essa prática pode evitar de pagar o mesmo ICMS duas vezes, pois se a SEFAZ/MT entende que não foi pago o imposto da nota fiscal, o referido débito é lançada para empresa, e a falta de controle pode fazer com que a empresa pague novamente um débito que pela substituição tributária já estava quitado, por falha da SEFAZ/MT em não identificar o pagamento via substituição.

Gráfico 09: Conferência das Notas Fiscais pagas via substituição tributária.

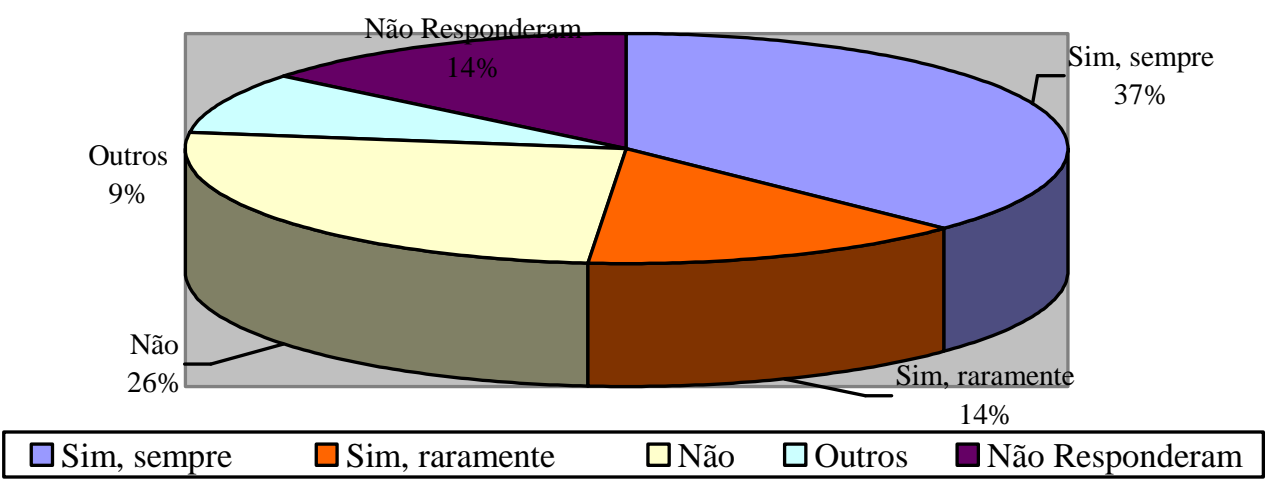

Fonte: dados da pesquisa.

Revista UNEMAT de Contabilidade, ano 1, n.1, jan./jun. 2012. 
Com isso, percebemos que $37 \%$ dos entrevistados afirmaram que sempre fazem essa conferência, $14 \%$ confirmaram que raramente é feito e 35\% não fazem a conferência ou estão em outras situações. Ressalta-se que os empresários estão corretos em fazer o controle das referidas operações, pois o processo de cobrança da SEFAZ/MT ainda não é confiável.

Aos que responderam sim, foi questionado aos empresários se através dos controles de conferências de notas fiscais já foi encontrado algum tipo de cobrança divergente ou duplicidade de cobranças do ICMS, assim o gráfico 10 confirma:

Gráfico 10: Identificação de cobranças divergentes.

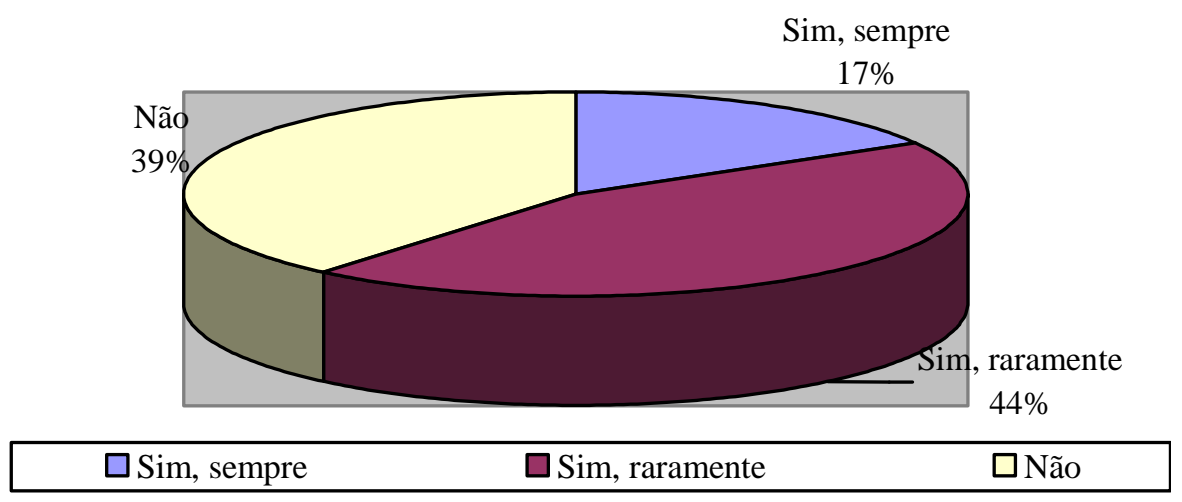

Fonte: dados da pesquisa.

Percebe-se que $61 \%$ responderam ter identificado cobranças em duplicidades, e $44 \%$ não encontraram cobranças indevidas. Considera-se que a SEFAZ/MT, segundo os empresários, efetua cobranças indevidas, que ocorrendo à falta de controles internos por parte da empresa o pagamento em duplicidade pode ocorrer com qualquer empresa.

Para confirmar o fato temos um exemplo real de cobrança em duplicidade de uma empresa do ramo farmacêutico em Tangará da Serra - MT, onde os dados de identificação foram preservados. A empresa, comprando de um fornecedor do Estado de São Paulo na qualidade de substituto tributário, há a retenção do ICMS conforme a nota fiscal eletrônica $\mathrm{n}^{\circ}$ 9493 de 31/01/2011 no valor total de 6.276,85 conforme a figura 01 adiante. Na nota fiscal há o destaque de retenção do ICMS no valor de 1.392,45, tendo como base de cálculo do imposto o valor de 4.431,66 mais o IPI de 354,74, ou seja, a base de cálculo do ICMS desta operação é de $4.786,40$.

Apesar do valor do ICMS retido ser de 1.392,45 e a base de cálculo ser de 4.786,40, verifica-se que o cálculo efetuado pelo fornecedor do imposto destacado e retido está incorreto, a maior, pois, comparando com a formação do valor ICMS, que a SEFAZ/MT calcula tem-se: 
Quadro 03: Cálculo do ICMS

\begin{tabular}{|l|c|c|l|l|l|l|l|l|}
\hline \multicolumn{4}{|l|}{ Conforme fornecedor dos produtos } & \multicolumn{4}{l|}{ Conforme SEFAZ/MT } & $\begin{array}{l}\text { Diferença a maior } \\
\text { dos Cálculos }\end{array}$ \\
\hline BC & MVA & Alíquota & ICMS & BC & MVA & Alíquota & ICMS & ICMS \\
\hline $4.786,40$ & $\mathrm{X}$ & $\mathrm{X}$ & $1.392,45$ & $4.786,40$ & $0,01 \%$ & $15 \%$ & 718,03 & 674,42 \\
\hline
\end{tabular}

Fonte: dados da pesquisa.

Ou seja, o fornecedor também pode causar gastos desnecessários aos seus clientes senão dominar corretamente o cálculo, pois neste caso o valor que deveria estar destacado era os 718,03, conforme cálculo do quadro 03. Voltando à cobrança em duplicidade, a empresa em questão pagou o ICMS retido conforme o Documento de Arrecadação do ICMS (DAR) no valor de 1.392,45, ilustrado adiante na figura 02, encerrando assim a cobrança do ICMS da operação, pois o ICMS é não cumulativo. No entanto, a SEFAZ/MT lançou novamente para a empresa recolher, conforme evidenciado no DAR de arrecadação do ICMS ilustrado na figura 03. Nele a SEFAZ/MT, informa o número da nota fiscal 9493, a data de emissão $31 / 01 / 2011$, o percentual de $15 \%$, a MVA de $0,01 \%$ e o valor total a pagar do ICMS de 718,03. Percebemos que realmente a cobrança indevida ocorre, visto que a empresa já havia pago por substituição tributária, porém, a SEFAZ/MT efetuou novamente a cobrança e se a empresa em questão não conferisse as notas provavelmente teria pago novamente o ICMS em questão, totalizando 2.110,40 de recolhimento de um ICMS, o qual o valor devido é de 718,03. Segue a seguir as figuras que comprovam a narrativa anterior: 


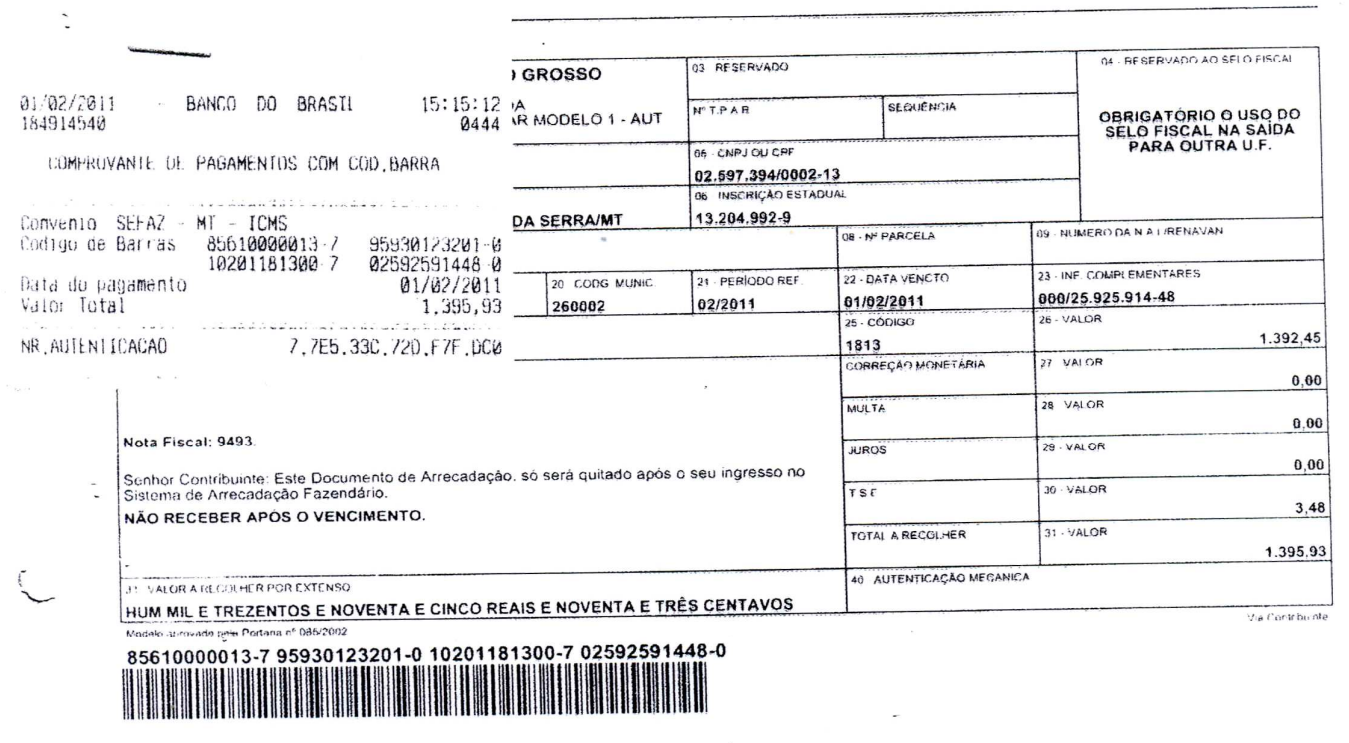

Figura 01: Documento de Arrecadação do ICMS pago via substituição tributária. 


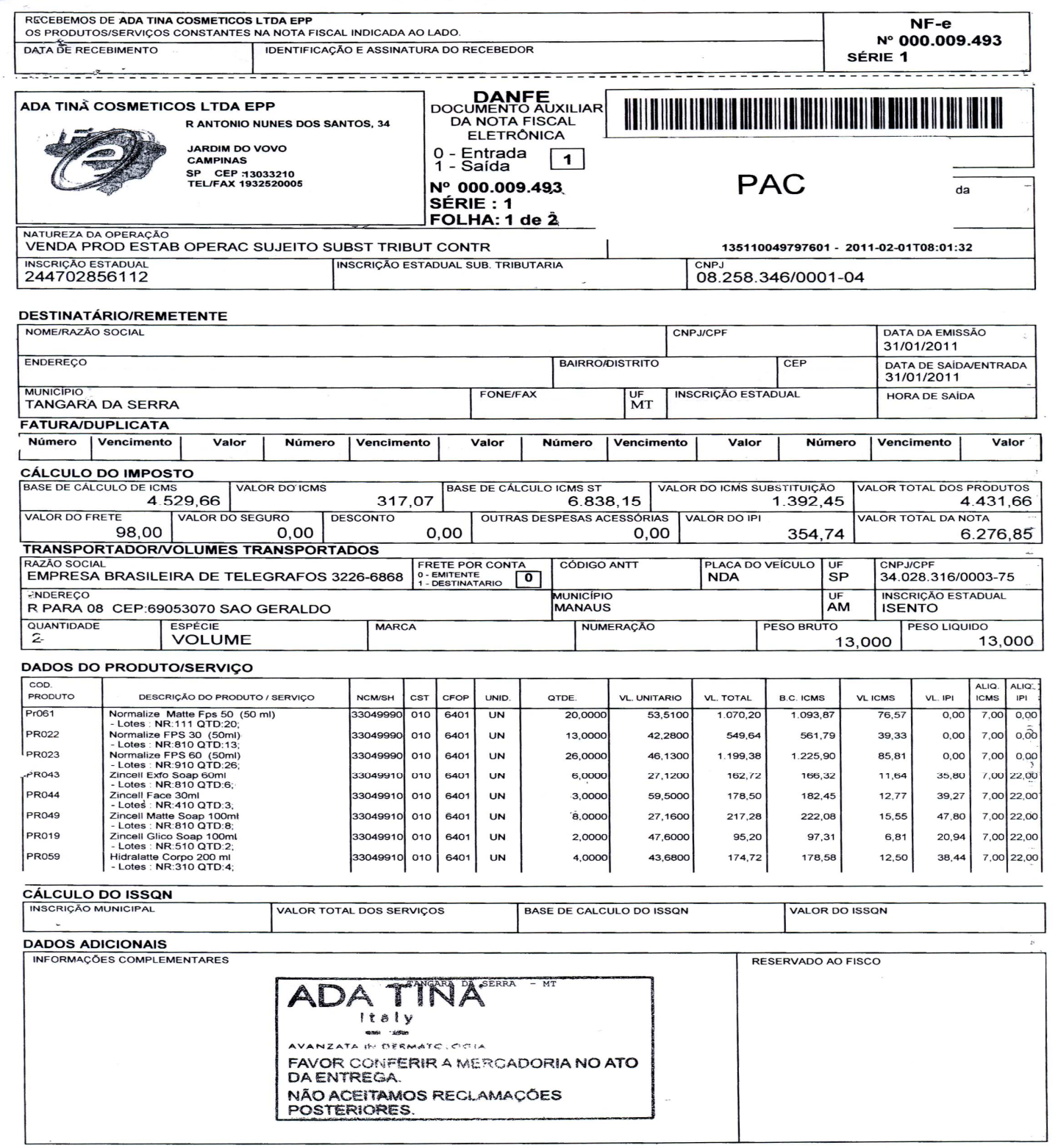

Figura 02: Nota fiscal com substituição tributária do ICMS. 


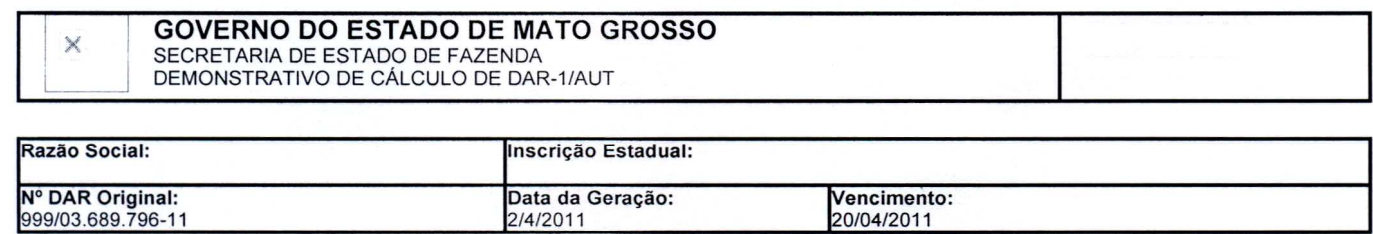

\begin{tabular}{|c|c|c|c|c|c|c|c|c|c|}
\hline $\mathbf{N}^{\circ} \mathrm{NF}$ & \begin{tabular}{c|} 
Data \\
Emissão
\end{tabular} & \begin{tabular}{|l} 
Aliquota \\
Orig|Des
\end{tabular} & Base Calculo & Valor IPI & Marg.Lucro & $\begin{array}{l}\text { Créd.IICMS } \\
\text { Ret. }\end{array}$ & Valor ICMS & CNPJ do Forncedor & Razão Social \\
\hline 904648 & $02 / 02 / 2011$ & $0 \quad 15$ & $1,095.09$ & 0.00 & 0.01 & 0.00 & 164.28 & $44.463 .156 / 0001-84$ & $\begin{array}{l}\text { SERVIMED } \\
\text { COMERCIAL LTDA }\end{array}$ \\
\hline 8942 & 03/02/2011 & 0 & 629.98 & 0.00 & 0.01 & 0.00 & 94.51 & 04.543.855/0001-10 & $\begin{array}{l}\text { FERROSAN DO } \\
\text { BRASIL LTDA }\end{array}$ \\
\hline 8943 & 03/02/2011 & 0 & 190.00 & 0.00 & 0.01 & 0.00 & 28.50 & $04.543 .855 / 0001-10$ & $\begin{array}{l}\text { FERROSAN DO } \\
\text { BRASIL LTDA }\end{array}$ \\
\hline 9493 & $31 / 01 / 2011$ & $0 \quad 15$ & $4,786.40$ & 0.00 & 0.01 & 0.00 & 718.03 & $08.258 .346 / 0001-04$ & ADA TINA \\
\hline 11142 & $11 / 02 / 2011$ & 015 & 928.50 & 0.00 & 0.01 & 0.00 & 139.29 & 06.194.426/0001-00 & $\begin{array}{l}\text { LTDA } \\
\text { MRA COMERCIO } \\
\text { DE COSMÉTICOS } \\
\text { LTDA. }\end{array}$ \\
\hline 956485 & 14/02/2011 & $0 \quad 15$ & 37.56 & 0.00 & 0.01 & 5.63 & 0.00 & $44.463 .156 / 0001-84$ & $\begin{array}{l}\text { SERVIMED } \\
\text { COMERCIAL LTDA }\end{array}$ \\
\hline 956485 & 14/02/2011 & $0 \quad 15$ & 234.89 & 0.00 & 0.01 & 29.68 & 5.56 & $44.463 .156 / 0001-84$ & $\begin{array}{l}\text { SERVIMED } \\
\text { COMERCIAL LTDA }\end{array}$ \\
\hline 956486 & $14 / 02 / 2011$ & $0 \quad 15$ & 482.24 & 0.00 & 0.01 & 0.00 & 72.34 & $44.463 .156 / 0001-84$ & $\begin{array}{l}\text { SERVIMED } \\
\text { COMERCIAL LTDA }\end{array}$ \\
\hline 956487 & 14/02/2011 & $0 \quad 15$ & 396.78 & 0.00 & 0.01 & 59.51 & 0.01 & $44.463 .156 / 0001-84$ & $\begin{array}{l}\text { SERVIMED } \\
\text { COMERCIAL LTDA }\end{array}$ \\
\hline 956488 & 14/02/2011 & $0 \quad 15$ & 309.51 & 0.00 & 0.01 & 34.34 & 12.09 & $44.463 .156 / 0001-84$ & $\begin{array}{l}\text { SERVIMED } \\
\text { COMERCIAL LTDA }\end{array}$ \\
\hline 957196 & $14 / 02 / 2011$ & $0 \quad 15$ & 68.30 & 0.00 & 0.01 & 10.14 & 0.11 & 44.463.156/0001-84 & $\begin{array}{l}\text { SERVIMED } \\
\text { COMERCIAL LTDA }\end{array}$ \\
\hline 988660 & 18/02/2011 & $0 \quad 15$ & 290.40 & 0.00 & 0.01 & 43.56 & 0.00 & $44.463 .156 / 0001-84$ & $\begin{array}{l}\text { SERVIMED } \\
\text { COMERCIAL LTDA }\end{array}$ \\
\hline 988660 & 18/02/2011 & $0 \quad 15$ & 414.58 & 0.00 & 0.01 & 23.11 & 39.08 & $44.463 .156 / 0001-84$ & $\begin{array}{l}\text { SERVIMED } \\
\text { COMERCIAL LTDA }\end{array}$ \\
\hline 54050 & $23 / 02 / 2011$ & 0 & $16,740.00$ & 0.00 & 0.01 & 0.00 & $2,511.25$ & $37.396 .017 / 0001-10$ & $\begin{array}{l}\text { MEDECOMERCE } \\
\text { COMERCIAL DE } \\
\text { MED E PRODUT }\end{array}$ \\
\hline 388135 & 04/02/2011 & $0 \quad 15$ & 280.71 & 0.00 & 0.01 & 0.00 & 42.11 & $60.409 .075 / 0446-05$ & $\begin{array}{l}\text { NESTLE BRASIL } \\
\text { LTDA }\end{array}$ \\
\hline 388136 & 04/02/2011 & $0 \quad 15$ & 646.68 & 0.00 & 0.01 & 0.00 & 97.01 & $60.409 .075 / 0446-05$ & $\begin{array}{l}\text { NESTLE BRASIL } \\
\text { LTDA }\end{array}$ \\
\hline 388137 & 04/02/2011 & $0 \quad 15$ & $1,300.60$ & 0.00 & 0.01 & 0.00 & 195.11 & $60.409 .075 / 0446-05$ & $\begin{array}{l}\text { NESTLE BRASIL } \\
\text { LTDA }\end{array}$ \\
\hline 388138 & 04/02/2011 & $0 \quad 15$ & 764.62 & 0.00 & 0.01 & 0.00 & 114.70 & $60.409 .075 / 0446-05$ & $\begin{array}{l}\text { NESTLE BRASIL } \\
\text { LTDA }\end{array}$ \\
\hline 388139 & 04/02/2011 & $0 \quad 15$ & $1,362.73$ & 0.00 & 0.01 & 0.00 & 204.43 & $60.409 .075 / 0446-05$ & $\begin{array}{l}\text { NESTLE BRASIL } \\
\text { LTDA }\end{array}$ \\
\hline 388140 & $04 / 02 / 2011$ & $0 \quad 15$ & 307.71 & 0.00 & 0.01 & 0.00 & 46.16 & $60.409 .075 / 0446-05$ & $\begin{array}{l}\text { NESTLE BRASIL } \\
\text { LTDA }\end{array}$ \\
\hline
\end{tabular}

valor do icms $(C 9)=[C 5 *(1-$ perc_reduc_base_calc_icms / 100 $) *(1+(C 7 / 100)) *(C 4 / 100)]-[(C 5-C 6) *$ $(\mathrm{C} 3 / 100)]-\mathrm{C} 8$

Onde:C3, C4, C5, C6, C7, C8, C9 são as colunas da tabela acima perc_reduc_base_calc_icms ( Decreto $\mathrm{nr} 2781 / 2004)=0 \%$

http://www.sefaz.mt.gov.br/servcontab/servicos/garantido/DemonstCalcDar.asp?Indice=4

Figura 03: Demonstrativo de Cálculo do ICMS lançado pela SEFAZ/MT.

Identificando a cobrança indevida, a empresa precisa entrar com um processo administrativo na SEFAZ/MT de Pedido de Revisão de Lançamento, para requerer o crédito 
do referido imposto, se for este o caso, seguindo todos os procedimentos previstos no RICMS/MT, tal processo, para todos aqueles empresários que entraram com processo administrativo foram feitos em sua maioria pelos escritórios de contabilidade, conforme gráfico 11.

Gráfico 11: Responsáveis pela elaboração de Processos Administrativos à SEFAZ/MT.

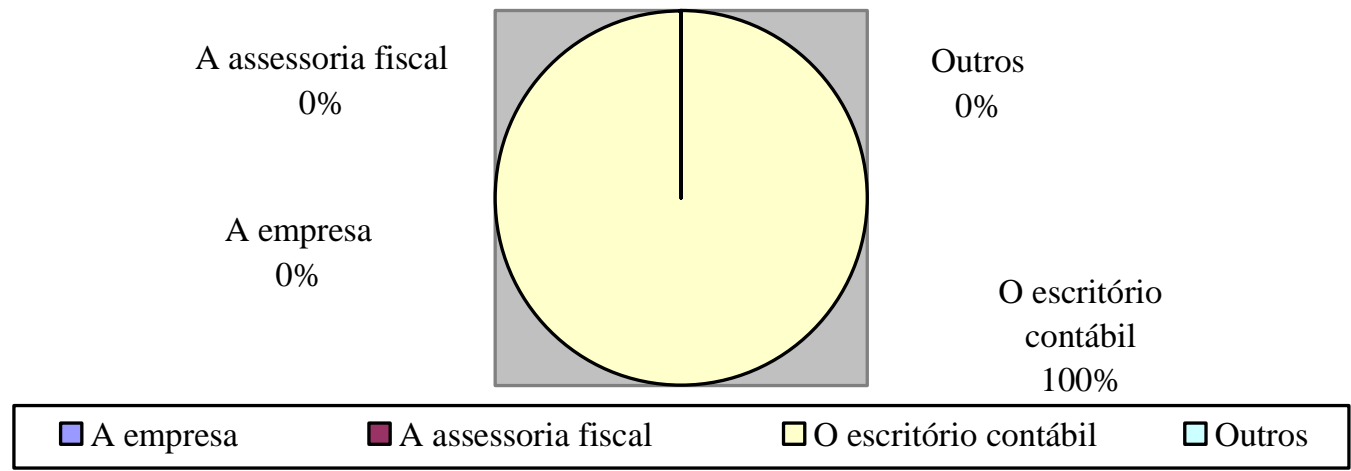

Fonte: dados da pesquisa.

O controle das notas fiscais já pagas via substituição tributária tem como finalidade evitar o pagamento em duplicidade, podendo evitar gastos que interferem nos resultados financeiros da empresa, sabe-se também que o custo/benefício para elaboração dos processos administrativos nem sempre são compensadores. Ao questionar todos os entrevistados se os mesmos já pagaram indevidamente algum valor de ICMS decorrente da falta de controles internos percebemos que há caso que a cobrança indesejada foi concretizada com a sua quitação, como demonstrado no gráfico 12 a seguir:

Gráfico 12: Pagamentos concretizados indevidamente.

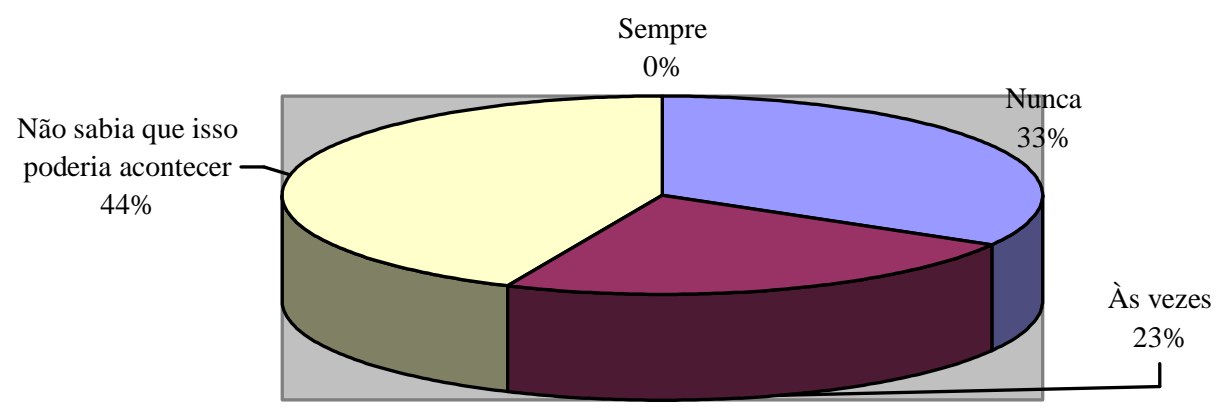

$\square$ Nunca $\square$ Às vezes $\square$ Não sabia que isso poderia acontecer $\square$ Sempre

Fonte: dados da pesquisa. 
É verificado que dos entrevistados $33 \%$ afirmaram que nunca efetuaram um pagamento indevido, entretanto $23 \%$ infelizmente já concretizaram uma quitação indevida e outros $44 \%$ responderam que não sabiam que isso poderia acontecer, todavia, verifica-se que a falta de informação por parte dos empresários pode influenciar nas tomadas de decisões da empresa, como por exemplo, autorizar um pagamento sem a devida conferência.

Quando os entrevistados foram questionados sobre estarem atualizados em relação à legislação do ICMS no Estado de Mato Grosso $72 \%$ afirmaram que sempre ou raramente procuram estar atualizados, e $11 \%$ confirmaram que não procuram estar atualizados como se pode perceber no gráfico 13:

Gráfico 13: Atualização dos entrevistados com relação à Legislação tributária do Estado.

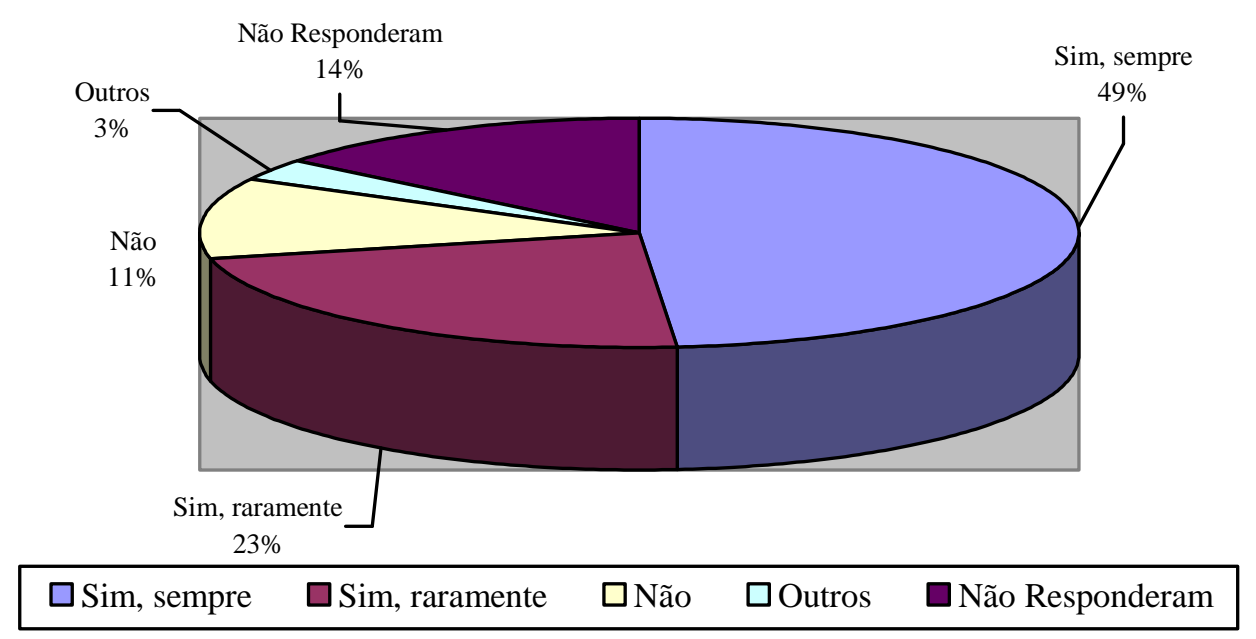

Fonte: dados da pesquisa.

Entretanto, apesar da maioria dizer que há a procura pela atualização das informações sobre o ICMS, as respostas entram em contradições, pois os gestores de uma empresa bem informada acertariam a maioria das questões objetivas, ou seja, a mesma proporção que procura estar atualizada, teoricamente teriam que acertá-las.

Provavelmente, o problema pode estar na sua assessoria fiscal que repassa as informações incompletas ou os próprios empresários não as compreendem como deveria. A seguir no gráfico 14 segue como as empresas procuram estar atualizadas em relação ao ICMS. 
Gráfico 14: Tipos de atualizações na legislações que os entrevistados procuram.

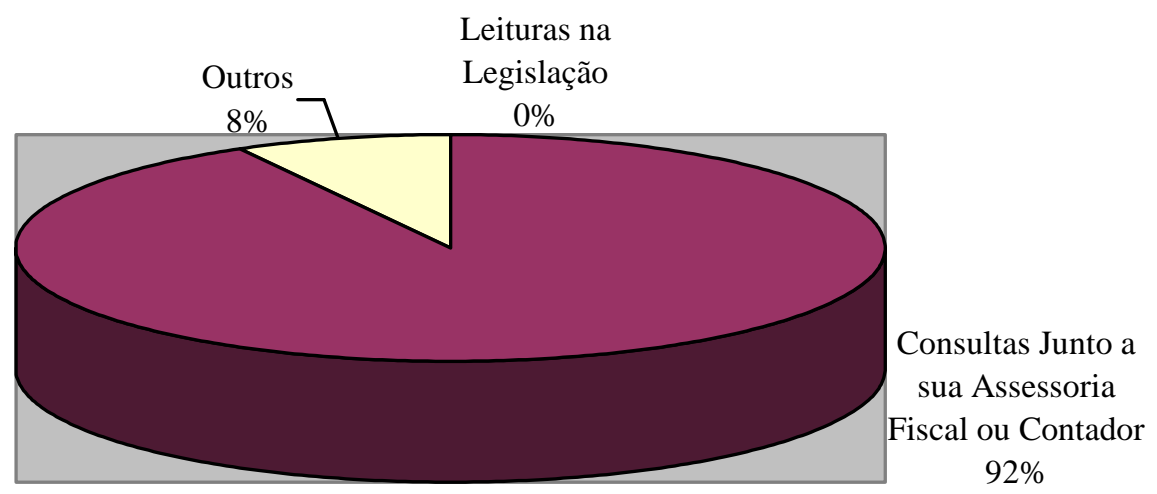

$\square$ Leituras na Legislação $\square$ Consultas Junto a sua Assessoria Fiscal ou Contador $\quad$ QOutros

Fonte: dados da pesquisa.

Com isso, dos que responderam sim, verificamos que $92 \%$ se atualizam em consulta as suas assessorias fiscais ou contadores.

Questionados em relação ao Decreto 392, de 30 maio de 2011, que institui o regime de cobrança do ICMS por Carga Média no Estado de Mato Grosso, onde o mesmo define um percentual de cobrança do ICMS para cada atividade econômica, foi pedido para que os empresários marcassem o percentual cobrado para o ramo farmacêutico, os resultados são demonstrados no gráfico 15 a seguir.

Gráfico 15: Alíquota definida para o ramo farmacêutico.

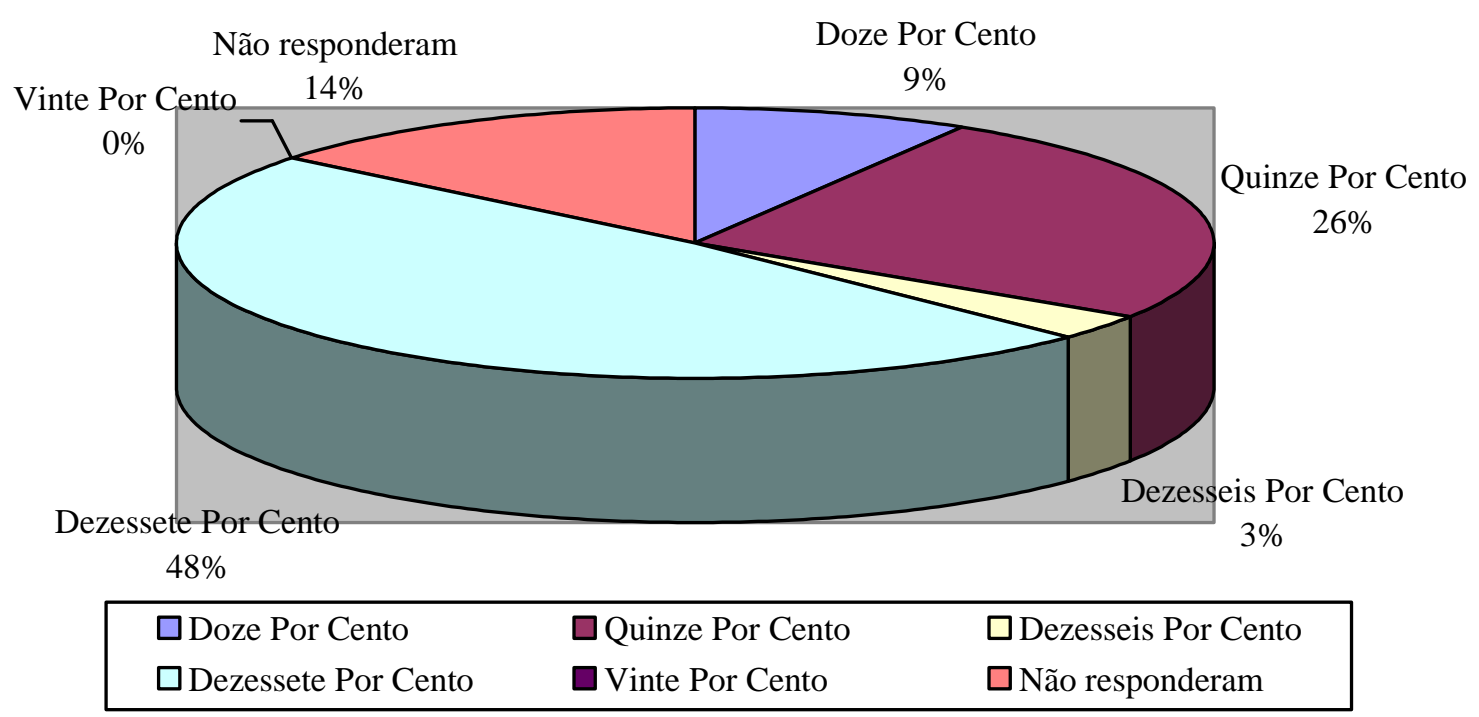


Fonte: dados da pesquisa.

De acordo com o Decreto 392 comentado anteriormente, para o ramo farmacêutico o percentual final cobrado para o setor é de $15 \%$, assim, com as respostas obtidas cerca de $26 \%$ dos entrevistados responderam a alternativa correta, ou seja, os $15 \%$, os restantes não acertaram, observa-se novamente que os empresários ainda fazem confusão em relação ao percentual obtido, pois a maioria marcaram na alternativa cujo valor é de $17 \%$, lembrando que $17 \%$ é a alíquota interna do ICMS no Estado de Mato Grosso.

Analisando a satisfação dos contribuintes em relação à atual gestão da SEFAZ/MT ressaltamos que o nível de satisfação não é uma das mais agradáveis para o Governo do Estado de acordo com as respostas obtidas no gráfico 16.

Gráfico 16: Satisfação dos entrevistados com relação a atual gestão da SEFAZ/MT.

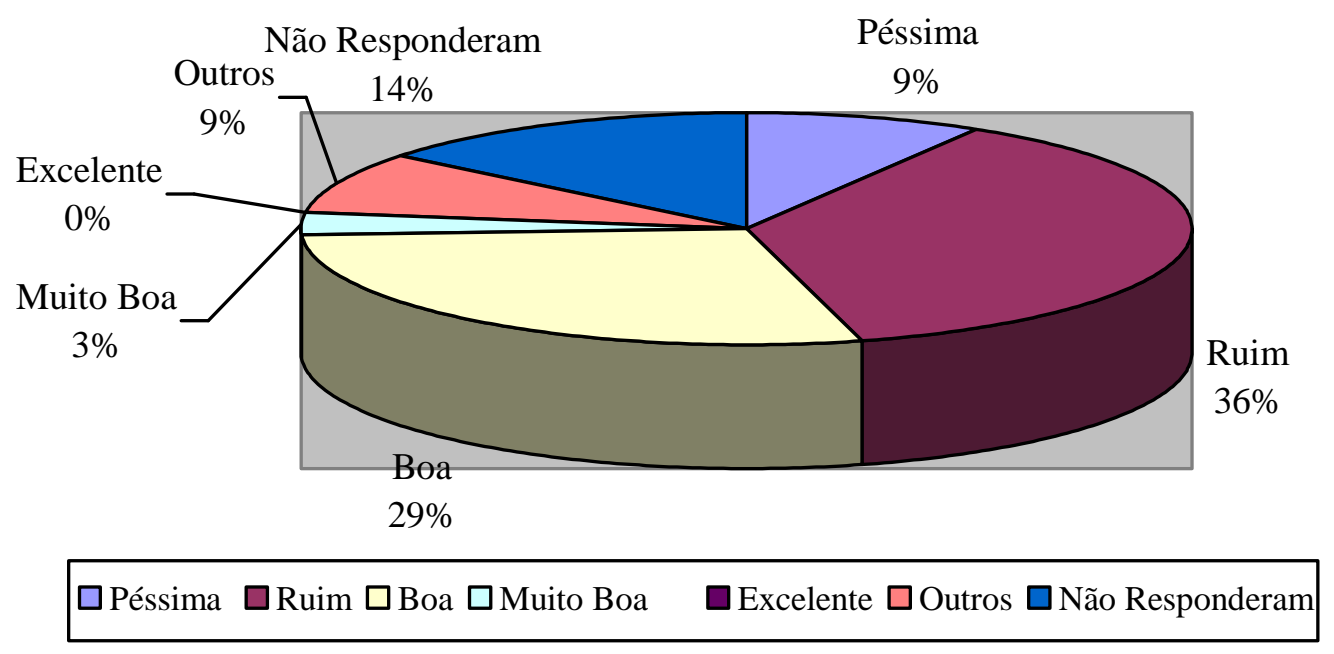

Fonte: dados da pesquisa.

Segundo os entrevistados $36 \%$ confirmaram uma satisfação ruim em relação à atual gestão da SEFAZ/MT, todavia, outros contribuintes afirmaram uma boa ou muito boa gestão da SEFAZ/MT, mostrando que há uma diversidade de opiniões dos empresários.

\section{CONSIDERAÇÕES FINAIS}

Em relação ao conhecimento dos empresários do ramo farmacêutico de Tangará da Serra - MT pode-se dividi-lo em três níveis de acordo com os 30 entrevistados, primeiramente os que sabem pouco ou quase nada em relação ao tema, cerca de $47 \%$ dos empresários se enquadram nessa classificação, mostrando que muitos empresários não buscam estar 
atualizados na legislação, os que se classificam neste nível responderam apenas uma ou nenhuma pergunta correta em relação ao tema abordado.

Outro grau de conhecimento dos empresários são os que possuem um conhecimento regular ou muito, ou seja, $37 \%$ dos empresários estão neste grupo, mostrando que o tema do ICMS Substituição Tributária não é algo desconhecedor de muitos dos empresários da cidade de Tangará da Serra - MT, os que se enquadram nesse cenário acertaram pelo menos duas questões, sabendo definir o que é o ICMS Substituição Tributária e ainda podem citar exemplos de produtos substitutos tributário. O terceiro nível seria os que possuem um conhecimento elevado ou excelente em relação ao tema, pois além de definir o que é ICMS Substituição Tributária, e quais os produtos que podem ser substitutos, ainda calculam o valor do imposto corretamente e podem mostrar a alíquota definida para o ramo farmacêutico no estado de Mato Grosso, cerca de 16\% dos empresários se enquadram nesse perfil, os que se enquadram nessa classificação acertaram pelo menos três questões.

O problema do setor farmacêutico é se há conhecimento por parte dos empresários em relação ao regime de substituição tributária do ICMS, e se há um acompanhamento dos pagamentos efetuados pelo regime de substituição tributária que previnam contra divergências relacionadas aos valores cobrados pela SEFAZ/MT, dessa maneira os problemas foram parcialmente respondidos e os objetivos foram atingidos, pois foi possível identificar qual o nível de conhecimento dos empresários do ramo farmacêutico de Tangará da Serra em relação ao ICMS Substituição Tributária. O acompanhamento das Notas Fiscais é feito pela maioria dos empresários e às cobranças indevidas considera-se comprovado a possibilidade de acontecer, no entanto, a forma mais simples de evitá-la é o controle das notas fiscais pagas via substituição tributária. A primeira hipótese foi validada parcialmente, pois se considera que há níveis de conhecimento pelos empresários do ramo farmacêutico de Tangará da Serra - MT, uns sabem mais que outros. A segunda hipótese foi totalmente validada, pois apresentava-se que pela falta de controle e conferência poderia ocorrer duplicidades de pagamento do ICMS decorrente das notas já pagas pelo regime de substituição tributária do ICMS/MT, mostrando que exemplos reais comprovaram o fato.

Como sugestão de estudos futuros, cita-se um complemento da pesquisa, mas voltado para outros setores da cidade de Tangará da Serra - MT, para que haja a comparação entre os níveis de conhecimentos e se há a cobrança indevida por parte da SEFAZ/MT em outros ramos de atividade da região. 


\section{REFERÊNCIAS BIBLIOGRÁFICAS}

BRASIL, Receita Federal do Brasil. Código Tributário Nacional. Da Lei 5.176 de 25 de outubro de 1966. Disponível em:

< http://www.receita.fazenda.gov.br/legislacao/codtributnaci/ctn >. Acesso em 24 de Abril de 2011.

BRASIL, Receita Federal do Brasil. Classificação Nacional de Atividades Econômicas / CNAE. Disponível em:

< http://www.receita.fazenda.gov.br/PessoaJuridica/CNAEFiscal/cnaef.htm >. Acesso em 24 de Abril de 2011.

BRASIL, Receita Federal do Brasil. NCM / SH - Nomenclatura Comum do Mercosul / Sistema Harmonizado de Designação e Codificação de Mercadorias. Disponível em:

$<$ http://www4.receita.fazenda.gov.br/simulador/glossario.html $>$. Acesso em 03 de setembro de 2011.

BRASIL, Constituição Federal (1988). Disponível em:

$<$ http://www.planalto.gov.br/ccivil_03/constituicao/constitui\%C3\%A7ao.htm>. Acesso em 24 de Abril de 2011

FABRETTI, Láudio Camargo. Contabilidade Tributária. $10^{\circ}$ Edição - São Paulo: Atlas, 2006.

MATO GROSSO, Secretária de Fazenda. Regulamento do ICMS do Estado de Mato Grosso. Atribuído pelo Decreto n. ${ }^{\circ}$ 1.944, de 06 de outubro de 1989, Mato Grosso. Disponível em:

$<$ http://app1.sefaz.mt.gov.br/sistema/legislacao/regulamentoicms.nsf $>$. Acesso em 16 de Abril de 2011.

MATO GROSSO, Secretária de Fazenda. Nova Regra de Cálculo do ICMS Substituição Tributária - Medicamentos. Mato Grosso. Disponível em:

<http://www.sefaz.mt.gov.br/portal/download/arquivos/Decreto_1845_2009_Medicamento_2 90409.pdf >. Acesso em 23 de Abril de 2011.

OLIVEIRA, Luis Martins. Manual de Contabilidade Tributária. $6^{\circ}$ Edição - São Paulo: Atlas, 2007. 
TANGARA DA SERRA, Prefeitura Municipal de Tangará da Serra. Departamento de Alvará. Consulta de Cadastro Técnico na Prefeitura Municipal de Tangará Serra - MT, 08 de abril de 2011. 